\title{
from 'Earth Per Verse - A Catalogue of Suspicions and Dreams'
}

\author{
Libby Scheier
}

\author{
Tiré de 'La terre en poème - \\ catalogue de soupçons et de rêves'
}

Allant d'un rêve qui décrit les différences perçues par un enfant entrela bitte et le con au réconfort litanique du Je offert à l'enfant Libby pour l'assurer qu'elle est maintenant en sécurité, cette séquence poétique raconte impitoyablement et en détail, en s'apuyant sur la reconstitution des rêves et des souvenirs, la dynamique émotionnelle, sociale et physiqued'un cas d'abus sexuel d' un enfant. 'La mémoire est une chose étrange une douleur étrange, ses petites flammes venant lécher et réveiller cette partie-ci du cerveau ou encore celle-là'. Comment cette violence se perpétue et se supporte en silence (il n'y a pas d'autre choixà ce moment-là), l'explication en est donnée de façon efficace dans le rêve des parents qui préface les souvenirs de leur fille. 
8.

dream on the train from Toronto to Kingston:

disembodied dicks move floaty through the air looking for mouths to hide in looking for warm and wet places to hide in be safe in be loved in so dis 'em bodied and vee-flying

in

formation

south

bound

like

canada

geese

the pussies sit resolutely on

their haunches their bodies

refusing to move refusing to go any

where smile

their floppy

hairy smiles

are part

of the

legs

and bellies

and anal

crevices

that come

together

in vulval

em

brace 
9.

dream of the father:

tree

my cheek against your bark

your grey and brown and black

roughness of skin your five o' clock

beard rubbed hard

on my five-year-old face

your leather belt zaps the air

electric eel

coming after me

SNAP SLAP SNAP SLAP

its black tongue sears my thigh red

I'm a fish on a rock far from water

(this is also a dream of the mother the mother in this dream speaks in whispered italics in audible after which silence always silence the mother in this dream lives in (side) parentheses) 
10.

the father's dream:

the dark cold basement in Bukavina soldiers' boots black potatoes springmud the sound shhhhhhhhhhhhhhhhhhh the sky breaking into yellow storm clouds bile vomit mucus blood the flesh-smelling earth sprayed in my face 
11.

and the mother's dream:

The house in Brooklyn, Mama up before the sun, making a fire in the stove, two beds and nine sleeping children. Maybe this morning I'll get the special kiss. But Mama leans over the pot of boiling water too far and one of her braids not yet circled primly around the crown of her head slips down along the outside of the pot and catches fire the fire eating its way up the twisted grey and yellow braid the orange flame licking salaciously at the faded yellow strands working its way slowly up to the ear and inside the ear all the way to the brain and the head explodes like an angry sun and I do not get the special kiss. 
14.

memory is a strange thing a strange sting its little brain flames hotting up this and that corner of skull till cells flare into snapshots and faint recordings and the tactile the sense of touch those words sound too soft and gentle for these brute remembered pieces and yes the sense of taste and smell are there like five-herb tea and five-flavor soup is five-senses memory like a full-course meal of shame flaming its way to anger but for now the pieces present themselves

small legs

in a courtyard and

long legs next to them and a hand is taken and he talks to her kindly and gently and she is pleased by the attention and they walk out of the hot sun into the cool and pleasant crumbly concrete basement dark of the building and

a large hand on a tiny vagina the choke in the throat from his arm-thing in a tiny mouth the taste of soft flesh become lethal like pokers the feel of her tongue on the veins the feel of the hard thing covered with flesh as warm as mother's hands the hard thing thudding into the walls of her mouth inside her mouth the hard thing covered with soft flesh battering the roof of her mouth the smell of cool stone and male sweat and the smell of the thing under her nose slamming into her mouth filling her mouth entirely her mouth collapsing around it like a balloon sucked inside out 
so sudden

who knows at first what it is it feels like an arm

whose hand was amputated the pink and pointy stump

insisting into the throat that this space

is stump space is his she can't breathe

when did the amputated-hand arm-thing withdraw from the mouth did it shoot its stuff first what happened after that how did he end it it was ended how did she leave the basement all that is missing the next snapshot is in the same tiny mouth it is the mouth telling what happened telling the adults the protectors what happened and nothing happening from the telling the next shot

is in the courtyard again at his mercy and being five and he is sixteen and your eight-year-old brother has been told to keep him away from you he's been told by your father who refuses to protect you and refuses to let your mother protect you and your mother doesn't stand up to him but does as she is told and Alan Turchin the child rapist at 1504 Ocean Avenue in Brooklyn New York Alan Turchin the son of the superintendent 
takes me by the arm and pulls me toward the basement again and my brother Michael takes my other arm and they tug-of-war me in the bright daylight and I long to break into two pieces one could die and go with Alan Turchin and one could live and stay with Michael and I don't break into two pieces but it's bright daylight and Alan Turchin gives up but I live there for two more years and I stand in the courtyard mouse hedgehog rabbit toad and every other small animal that ever longed for a dark safe hole to hide in but the only hole to hide in is the basement and I can't go upstairs I've been told to go out and play so there's no refuge and no play there's just watching him carefully and hoping he won't and after giving up at tug-of-war he doesn't and he doesn't say anything to me about what he did and he doesn't tell the children in the courtyard about it but what he does is he divides me out drydusty chaff from kernels of wheat rind from fruit used goods from new and mocks me over and over and over always in front of an audience of children and he beats me with words for two years and I am a leper and I am hurt and puzzled and scared and alone more than anything I am alone and my name is Libby not Jenny and this happened to me 
15.

I roli my eyeballs back into my head and look down inside

my body and see a steel box around my heart and I hot my eyeballs up and superman-stare it and stare and stare and stare and focus and the box drips a little at the corners and begins to melt away off in a corner an image lights up and I look and it is a tiny heart racing away away away beating like crazy scared as shit and it's out of my body racing away it's hanging in the air a mobile without wires a creature from outer space and I inhale deeply and roll my eyeballs outward toward the heart and I inhale deeply and attach my gaze like a magnet to the tiny heart and I reel it in like a fish my gaze-hook in its folds and the little hook-hole a bleeding mouth and my eyeballs feel the pulse pulse of the tiny heart and I reel it in rolling my pupils upward with each turn of the reel then down then up again and I inhale deeply and it comes to me slowly and slowly and slowly but it comes and I inhale deeply and here it is and I open my kind adult-woman mouth and take the tiny heart into it curling my tongue around it gently and roll it back toward my throat and I inhale deeply and the heart goes down with the breath and I swallow and it goes down my throat gently like a peeled plum it goes down home back to the place it ran away from back now because it's safe I promise it's safe now I promise, Libby,

I promise 